\title{
neonatal medicine
}

\section{A Novel MUT Gene Mutation Detected in a Female Infant with Methylmalonic Acidemia}

Woo Sun Song, M.S., M.D., Byung Jin Song, M.D., Hyung-Doo Park, M.D.*, and Won Duck Kim, M.D. Department of Pediatrics, Daegu Fatima hospital, Daegu, Department of Laboratory Medicine and Genetics*, Samsung Medical Center, Sungkyunkwan University School of Medicine, Seoul, Korea

\section{ABSTRACT}

Methylmalonic acidemia (MMA) is an autosomal recessive metabolic disease. MMA results from a deficiency of L-methylmalonyl-CoA mutase (encoded by $M U T$ ), its cofactor 5-deoxyadenosylcobalamin (MMAA, MMAB, and MMADHC), or a deficiency of methylmalonyl CoA-epimerase (MCEE). We report the case of a 5-day-old infant with MMA in which a missense and a novel nonsense mutation in MUT were present. Direct sequencing analysis of $M U T$ revealed a heterozygous c.1106G $>$ A (p.Arg369His) mutation in exon 6 and a heterozygous c.362_368dupAGTTCTA (p. Tyr $\left.123^{*}\right)$ mutation in exon 2; the latter results in a premature stop codon.

Key Words: Methylmalonic acidemia, L-methylmalonyl-CoA mutase, Nonsense mutation

\section{서론}

메틸말론산혈증(methylmalonic acidemia)은 상염색체 열성으로 유전되는 선천성 대사장 애 질환으로 분자쇄(branched chain) 아미노산과 지방산의 대사 과정 중 L-methylmalonyl $\mathrm{CoA}$ 에서 succinyl $\mathrm{CoA}$ 로 대사되는 과정에 관여하는 효소인 methylmalonyl CoA mutase 와 조효소인 adenosylcobalamine의 장애가 있어 메틸말론산이 혈중에 과다하게 축적되고 요 중으로도 과잉 배설되는 것이 특징이다1).

메틸말론산혈증은 주효소 결핍(mut) 유형과 B12 대사장애(Cbl) 유형으로 분류한다. $M U T$ 유형은 완전 결핍형태인 $m u t^{0}$, 부분결핍인 $m u t^{-}$로 다시 나뉘며, $m u t^{0}$ 유형은 주효소의 활성이 $0.1 \%$ 미만에서 나타나며 대사성 산증이 생후 1 주일 이내로 보이게 된다. mut 유형 은 1 세 이후 감염에 의한 반복적인 케톤혈증이 보이게 된다. 대부분의 환자는 신생아기부터 반복되는 구토와 탈수, 대사성 산증이 나타나며 치료를 받지 않으면 대개 영아기에 사망한 다2).

저자들은 수유 곤란 및 탈수를 주소로 내원한 생후 5일된 신생아에서 분자유전학적 분석 을 통하여 methylmalonyl-CoA mutase (MUT)의 새로운 유전자 돌연변이에 의한 메틸말론
Received: 20 October 2014

Revised: 14 January 2015

Accepted: 14 January 2015

Correspondence to:

Won Duck Kim, M.D.

Department of Pediatrics, Daegu

Fatima Hospital 183, Ayang-ro,

Dong-gu, Daegu, Korea

Tel: +82-53-940-7246

Fax: +82-53-954-7417

E-mail: 0101turtle@gmail.com

Copyright(c)

By Korean Society of Neonatology.

All right reserved.

This is an Open-Access article distributed under the terms of the Creative Commons Attribution Non-Commercial License (http://creativecommons.org/licenses/ by-nc/3.0), which permits unrestricted non-commercial use, distribution, and reproduction in any medium, provided the original work is properly cited. 
산혈증으로 진단된 1례를 경험하였기에 보고하고자 한다.

\section{증례}

재태주령 $38^{+1}$ 주, 출생체중 $2.79 \mathrm{~kg}$ (5-10 백분위)으로 정상 질 식 분만으로 대구에 소재한 개인병원에서 출생하였으며, 출생 당 시에 외형은 이상 소견은 보이지 않았으나, 출생 이후 3 시간 간격 으로 10-30 cc로 수유 시도시에 진행이 잘 되지 않았다. 생후 5일 째 수유곤란이 지속되고 체중이 감소되어 본원 응급실을 통하여 입원하였다.

입원당시 환자의 체중은 $2.49 \mathrm{~kg}$ (3 백분위수 미만), 신장 50 $\mathrm{cm}$ (25-50 백분위수), 두위 $33 \mathrm{~cm}$ (10-25 백분위수), 흥위 29 $\mathrm{cm}$ 이었다. 체온 $36.6^{\circ} \mathrm{C}$, 맥박수 148 회/분, 호흡수 56 회/분을 보 였으며 활동도는 감소되어 있었고, 입원 이후 24 시간 동안 소변 은 3 회 확인되었다. 의식은 명료하지 않고 호흡은 거칠고 심박동 은 정상이었으며, 심잡음은 들리지 않았다. 복부 검사상 간비종대 는 관찰되지 않았고, 이학적 검사에서 근력이 감소되어 있었다. 입원당시 동맥가스 소견상 $\mathrm{pH} 7.381$, 산소 분압 $113.1 \mathrm{mmHg}$, 이 산화탄소 분압 $15.3 \mathrm{mmHg}$, base excess $-13.1 \mathrm{mmol} / \mathrm{L}, \mathrm{HCO}_{3}$ $8.9 \mathrm{mEq} / \mathrm{L}$, 백혈구수 $4,830 / \mathrm{mm}^{3}$, 혈색소 $14.4 \mathrm{~g} / \mathrm{dL}$, 헤마토크리 트 39.2\%, 혈소판수 $221,000 / \mathrm{mm}^{3}$, AST/ALT 185/41 U/L, BUN/ Creatinine $17.1 / 0.9 \mathrm{mg} / \mathrm{dL}$ 소견을 보였다.

입원 2일째 움직임이 감소하고, 자극해도 자극에 반응 보이지 않고 혼미 단계의 의식수준 평가 및 불규칙한 호흡 양상이 관찰 되었다. 동맥가스 소견에서 $\mathrm{pH} 7.208$, 산소 분압 $101.4 \mathrm{mmHg}$, 이산화탄소 분압 $42.6 \mathrm{mmHg}$, base excess $-10.9 \mathrm{mmol} / \mathrm{L}, \mathrm{HCO}_{3}$ $16.6 \mathrm{mEq} / \mathrm{L}$, 암모니아 $2,135 \mathrm{umol} / \mathrm{L}$, 백혈구수 $2,260 / \mathrm{mm}^{3}$, 혈색 소 $13.5 \mathrm{~g} / \mathrm{dL}$, 헤마토크리트 $36.3 \%$, 혈소판수 $158,000 / \mathrm{mm}^{3}$, AST/ALT 194/44 U/L, BUN/Creatinine 19.61/0.74 mg/dL 소견 을 보였다. 뇌 단층촬영검사에서는 특이 소견이 없었다. 수액요법 과 알칼리요법을 시행하면서 고암모니아 혈증 소견으로 복막투 석을 시행하였고 호흡곤란으로 인공호흡기에 의한 보조 환기 치 료를 시작하였다.

입원 5일째 시행한 광범위 신생아 선천성 대사이상 선별 검사 에서 methylmalonic acidemia와 propionic acidemia에서 보이는

Table 1. Urine Organic Acid Analysis Results

\begin{tabular}{lcc}
\hline Organic acid & $\begin{array}{c}\text { Result } \\
\text { (mmol/mol } \\
\text { creatinine) }\end{array}$ & $\begin{array}{c}\text { Reference range } \\
\text { (mmol/mol } \\
\text { creatinine) }\end{array}$ \\
\hline 3-Hydroxypropionic acid & 3.8 & $0.0-0.8$ \\
Methylmalonic acid & $3,855.0$ & $0.0-27.3$ \\
Methylcitric acid & 60.0 & $0.0-0.0$ \\
4-Hydroxyphenyl lactic acid & 907.0 & $1.6-44.0$ \\
\hline
\end{tabular}

propionylcarnitine이 증가된 소견이 나타났다. 혈장 아미노산 분 석에서는 비특이적인 소견을 보였고, 혈청 젖산은 $12.69 \mathrm{mmol} / \mathrm{L}$ 로 증가되었다. 소변 유기산 분석 검사 결과에서 methylmalonic acid $3,855 \mathrm{mmol} / \mathrm{mol}$ Creatinine (정상 범위 0.0-27.3 mmol/mol Creatinine), 3-hydroxypropionic acid $3.8 \mathrm{mmol} / \mathrm{mol}$ Creatinine (정상 범위 $0.0-0.8 \mathrm{mmol} / \mathrm{mol}$ Creatinine)의 증가 소견과 함께 methylcitric acid $60.0 \mathrm{mmol} / \mathrm{mol}$ Creatinine (정상범위 0.0-0.0 $\mathrm{mmol} / \mathrm{mol}$ Creatinine), 4-hydroxyphenyl lactic acid 907.0 $\mathrm{mmol} / \mathrm{mol}$ Creatinine (정상범위 $1.6-44.0 \mathrm{mmol} / \mathrm{mol}$ Creatinine)로 동반 증가 소견을 보였다(Table 1).

분자유전학적 검사를 위하여 환자의 말초혈액에서 $\mathrm{DNA}$ 를 추 출하였으며, methylmalonyl-CoA mutase (MUT)의 유전자, 조효 소 5-deoxyadenosylcobalamin 유전자 $(M M A A, M M A B)$ 의 모든 엑손과 주변 인트론을 직접염기서열분석법으로 검사하였다. $M M A A$ 및 $M M A B$ 유전자에서는 돌연변이가 관찰되지 않았으나, MUT 유전자에서 c.1106G>A와 c.362 368dupAGTTCTA 등 2개 의 돌연변이가 발견되었다. c.1106G>A (p.Arg369His)는 기존에 질환의 원인 돌연변이로 알려진 것이며, c.362_368dupAGTTCTA (p.Tyr123*)는 신규 돌연변이로서 아미노산 서열의 조기 종료를 유발하는 중복 돌연변이였다(Figure 1).

입원 6일째 동맥가스 소견은 $\mathrm{pH} 7.429$, 산소 분압 155.3 $\mathrm{mmHg}$, 이산화탄소 분압 $35.3 \mathrm{mmHg}$, base excess $-0.9 \mathrm{mmol} /$

Table 2. Mutations of MUT Genes in Patients with Methylmalonic Acidemia. From Lee EH, et al. Korean J Pediatr 2008;51: 964-70 [18].

\begin{tabular}{|c|c|c|}
\hline Patient & Nucleotide change & Amino acid substitution \\
\hline \multirow[t]{2}{*}{1} & c. $1031 \mathrm{~T}>\mathrm{A}$ & S344Y \\
\hline & c. $1481 \mathrm{~T}>\mathrm{A}$ & L494X \\
\hline \multirow[t]{2}{*}{2} & c. $356 \mathrm{G}>\mathrm{A}$ & S119N \\
\hline & c. $2179 \mathrm{C}>\mathrm{T}$ & $\mathrm{R} 727 \mathrm{X}$ \\
\hline \multirow[t]{2}{*}{3} & c. $682 \mathrm{C}>\mathrm{T}$ & R3228X \\
\hline & c. $1481 \mathrm{~T}>\mathrm{A}$ & L494X \\
\hline \multirow[t]{2}{*}{4} & c.91 C>T & R31X \\
\hline & c.349 G>T & E117X \\
\hline \multirow[t]{2}{*}{5} & c. $322 \mathrm{C}>\mathrm{T}$ & $\mathrm{R} 108 \mathrm{C}$ \\
\hline & c. $323 \mathrm{G}>\mathrm{A}$ & $\mathrm{R} 108 \mathrm{H}$ \\
\hline \multirow[t]{2}{*}{6} & c. $349 \mathrm{G}>\mathrm{T}$ & $\mathrm{E} 117 \mathrm{X}$ \\
\hline & c. $1105 \mathrm{C}>\mathrm{T}$ & R369C \\
\hline \multirow[t]{2}{*}{7} & c. $349 \mathrm{G}>\mathrm{T}$ & E117X \\
\hline & c.1505_61del & V502DfsX11 \\
\hline \multirow[t]{2}{*}{8} & c. $1481 \mathrm{~T}>\mathrm{A}$ & L494X \\
\hline & c. $323 \mathrm{G}>\mathrm{A}$ & $\mathrm{R} 108 \mathrm{H}$ \\
\hline 9 & c.362_368dupAGTTCTA* & Y123X \\
\hline
\end{tabular}

*Novel mutation 


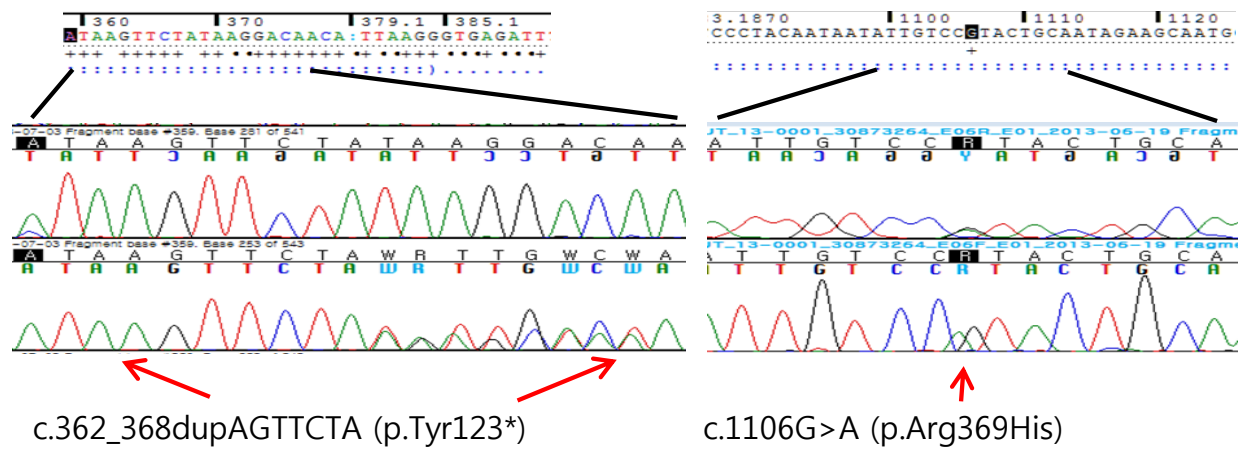

Figure 1. Direct sequencing analysis of the MUTgene, showing the heterozygote c.362_368dupAGTTCTA (p.Tyr123*) mutation in exon 2 and the heterozygote c.1106G>A (p.Arg369His) mutation in exon 6.

$\mathrm{L}, \mathrm{HCO}_{3} 23.0 \mathrm{mEq} / \mathrm{L}$, 암모니아 $122 \mathrm{umol} / \mathrm{L}$, 백혈구수 4,590/ $\mathrm{mm}^{3}$, 혈색소 $11.4 \mathrm{~g} / \mathrm{dL}$, 헤마토크리트 $31.9 \%$, 혈소판수 $143,000 /$ $\mathrm{mm}^{3}$, AST/ALT 43/5 U/L, BUN/Creatinine 28.8/2.50 mg/dL을 보였다.

입원 7일째 소변 양 충분하여 복막 투석 치료 중단 하였으며, 입원 9일째 동맥가스 검사는 $\mathrm{pH} 7.627$, 산소 분압 $128.1 \mathrm{mmHg}$, 이산화탄소 분압 $23.4 \mathrm{mmHg}$, base excess $4.6 \mathrm{mmol} / \mathrm{L}, \mathrm{HCO}_{3}$ $24.0 \mathrm{mEq} / \mathrm{L}$, 암모니아 $103 \mathrm{umol} / \mathrm{L}$ 소견을 보이고 자가 호흡 원 활하여 인공호흡 치료를 중단하였고 비 경구영양법과 함께 특수 조제 분유로 영양공급을 시작하였다. 입원 34일째 퇴원하였고 연 고지 관계상 일본에서 계속 경과 관찰 중이다.

\section{고찰}

메틸말론산혈증은 methylmalonyl-CoA mutase의 완전 혹은 부분적인 결핍 및 methylmalonyl-CoA의 조효소(cofactor)인 adenosyl-cobalamin ( $c b 1 A, c b l B, c b I D$ variant 2 type)의 결함, 그리고 methylmalonyl-CoA epimerase 효소의 결핍에 의해서 유 발된다3,4).

신생아 시기에는 무기력증, 구토, 근긴장 저하, 저체온증, 호흡 곤란, 심한 케톤산증, 고암모니아혈증, 백혈구 감소증, 혈소판 감 소증이 나타날 수 있으며, 이로 인하여 사망에 이를 수 있다2).

영유아 시기에는 non-B12-responsive phenotype의 경우, 출 생 직후에는 정상적이나 출생 이후 성장과정에서 무기력증, 구토, 탈수, 간비대증, 근긴장 저하, 뇌증이 발생한다. 중간형의(intermediated)-B12-responsive phenotype의 경우, 일부 신생아시 기에서 증상이 나타나고, 대부분 출생 한달 이후 혹은 1 세 이후에 증상이 나타난다. 영향을 받은 환자의 경우 거식증, 성장장애, 근 긴장 저하, 발달지연 및 단백질 혐오감 및 단백제품 섭취후 구토 무기력증 양상을 보이기도 한다. 비전형적인 성인에서의 메틸말 론산혈증에서는 메틸말론산이 소변에서 경하게 보일 수 있다. 주
요 이차적인 부작용으로 발달지연, 신부전으로 진행되는 세뇨관 간질성 신염, 무도 무정위 운동, 근긴장 저하, 사지불완전 마비, 부 분적 하반신 마비 및 췌장염, 시신경 위축증이 나타난다5-8).

메틸말론산혈증은 유형에 따라 $M U T, M M A A, M M A B, M C E E$, $M M A D H C$ 의 유전자의 돌연변이에 의해 발생하는 것으로 알려져 있으며 환자에서 발견되는 돌연변이 중에서 $M U T, M M A A$, $M M A B$ 유전자 부위의 돌연변이가 각각 약 $60 \%, 25 \%, 12 \%$ 를 차 지하고 있다고 보고되고 있다).

Methylmalonyl-CoA mutase의 유전자인 $M U T$ 는 chromosome의 6p12.3에 위치하며, methylmalonic acduria type A protein의 유전자인 $M M A A$ 는 $4 \mathrm{q} 31.21, \operatorname{cob}(\mathrm{I}) \mathrm{yrinic}$ acid a, $\mathrm{c}^{-}$ diamide adenosyltransferase의 유전자인 $M M A B$ 는 12q24.11, methylmalonyl-CoA epimerase의 유전자인 $M C E E$ 는 2p13.3, methylmalonic aciduria and homocystinuria type D protein의 유전자인 $M M A D H C$ 는 2q23.2에 위치한다9).

이 환자의 유전자 염기서열 분석 결과로 $M M A A$ 및 $M M A B$ 유 전자에서는 돌연변이가 없었으며, $M U T$ 유전자에서 c. $1106 \mathrm{G}>\mathrm{A}$ 와 c.362_368dupAGTTCTA 2개의 돌연변이가 발견되었다. c.1106G>A (p.Arg369His)는 이전에 질환의 원인 돌연변이로 알 려진 것이며, c.362_368dupAGTTCTA (p.Tyr123*)는 신규 돌연 변이로서 아미노산 서열의 조기 종료를 유발하는 중복 돌연변이 였다. 현재까지 120 여개의 $M U T$ 유전자의 돌연변이가 보고되었 으며 이번 연구에서는 기존에 보고되지 않은 엑손 2 번에서 p. Tyr123* 돌연변이가 확인되었다 ${ }^{10-14)}$

일반적인 메틸말론산혈증의 치료는 $10 \%$ 혹은 $12.5 \%$ 의 포도당 수액 요법과 함께 정맥 혹은 동맥 혈액가스 분석에서 나타나는 염기 및 수분 부족을 보충해야 한다. 중심 혹은 말초 정맥을 통한 총 비경구 영양법을 통하여 적절한 칼로리의 공급이 필요하다. 카 르니틴(carnitine)을 정맥으로 공급해야 할 경우도 있으며 소변 배출(urine output) 및 혈청 나트륨의 관찰(monitor)이 필요하다. 조절되지 않는 산증이나 고암모니아 혈증이 나타날 경우 혈액 및 복막투석이 필요한 경우도 있다 ${ }^{15-17)}$. 
본 증례의 환자의 경우 입원 당시 고암모니아 혈증 및 대사성산 증이 관찰되어 복막투석을 시행하였고 이후 특수 조제 분유 및 비경구영양법을 통하여 영양을 공급하였다. 현재 퇴원하여 연고 지 관계상 일본에서 계속 경과 관찰 중이다. 본 환자는 효소 활성 도 검사를 시행하지 않아 $m u t^{0}$ 혹은 $m u t^{-}$로 구분할 수 없었다. 국 내에서 메틸말론산혈증에 대한 보고가 있었으나 기존의 환자에서 관찰되지 않았던 새로운 $M U T$ 유전자에서 아미노산 서열의 조기 종결을 유발하는 새로운 중복 돌연변이인 c.362_368dupAGTT CTA (p.Tyr123*)에 의해서 메틸말론산혈증이 발견되어 보고하 는 바이다(Table 2$)^{18-19)}$.

\section{REFERENCES}

1) Fenton WA, Rosenberg LE. Disorders of propionate and methylmalonate metabolism. In: Scriver CR, Beaudet AL, Sly WS, Valle D, editors. The metabolic and molecular bases of inherited disease. 7th ed, New York : McGraw-Hill Inc, 1995; 1423-49.

2) Hörster F, Hoffmann GF. Pathophysiology, diagnosis, and treatment of methylmalonic aciduria-recent advances and new challenges. Pediatr Nephrol 2004;19:1071-4.

3) Deodato F, Boenzi S, Santorelli FM, Dionisi-Vici C. Methylmalonic and propionic aciduria. Am J Med Genet C Semin Med Genet 2006;142:104-12.

4) Fenton WA, Gravel RA, Rosenblatt DS. Disorders of propionate and methylmalonage metabolism: the metabolic and molecular bases of inherited disease. New York : McGrawHill, 2001;2165-93.

5) Wolff JA, Storm C, Griswold W, Sweetman F, Kulovich S, Prodanos C, et al. Proximal renal tubular acidosis in methylmalonic acidemia. J Neurogenet 1985;2:31-9.

6) Yamaguchi K, Hirabayashi $K$, Honma K. Brain lesion in a case of vitamin B12 non-responsive(mut0) type. Clin Neuropathol 1985;14:216-22.

7) Robb RM, Downton SB, Fulton AB, Levy HL. Retinal degeneration in vitamin B12 disorder associated with methylmalonic aciduria and sulfur amino acid abnormalities. Am J Ophthalmol 1984;97:691-6.

8) Stromme P, Stokke O, Jellum E, Skjeldal OH, Baumgartner R. Atypical methylmalonic aciduria with progressive encephalopathy, microcephaly and cataract in two sibling-a new recessive syndrome? Clin Genet 1995;48:1-5.

9) Pagon RA, Adam MP, Ardinger HH, Bird TD, Dolan CR, Fong CT, et al. GeneReviews ${ }^{\oplus}$ [internet]. Seattle, WA: University of Washington, Seattle; 1993-2014. Methylmalonic Acidemia. [cited 2014 Oct 20]. Available from: http://www.ncbi.nlm.nih. gov/books/NBK1231/

10) Sakamoto $O$, Ohura T, Matsubara $Y$, Takayanagi M, Tsuchiya $S$. Mutation and haplotype analyses of the MUT gene in Japanese patients with methylmalonic academia. J Hum Genet 2007; 52:48-55.

11) Kobayashi A, Kakinuma H, Takahashi $H$. Three novel and six common mutations in 11 patients with methylmalonic academia. Pediatr Int 2006;48:1-4.

12) Acquaviva C, Benoist JF, Pereira S, Callebaut I, Koskas T, Porquet D, et al. Molecular basis of methylmalonyl CoA mutase apoenzyme defect in 40 European patients affected by mut0 and mut- forms of methylmalonic academia: identification of 29 novel mutations in the MUT gene. Hum Mutat 2005;25:16776.

13) Merinero B, Perez B, Perez-Cerda C, Rincon A, Desviat LR, Martinez MA, et al. Methylmalonic academia: examination of genotype and biomedical data in 32 patients belonging to mut, cb1A or cb1B complementation group. J Inherit Metab Dis 2008;31:55-66.

14) Imataka $G$, Sakamoto $O$, Yamanouchi $H$, Yoshihara S, OmuraHasegawa Y, Tajima G, et al. Novel c.2216T > C (p.I739T) mutation in exon 13 and c.1481T > A (p.L494X) mutation in exon 8 of MUT gene in a female with methylmalonic acidemia. Cell Biochem Biophys 2013;67:185-7.

15) Satoh $T$, Narisawa K, Igarashi $Y$, Saitoh $T$, Hayasaka K, Ichinohazama Y, et al. Dietary therapy in two patients with vitamin B12-unresponsive methylmalonic acidemia. Eur J Pediatr 1981;135:305-12.

16) van der Meer SB, Poggi F, Spada M, Bonnefont JP, Ogier $H$, Hubert $\mathrm{P}$, et al. Clinical outcome of long-term management of patients with vitamin B12-unresponsive methylmalonic acidemia. J Pediatr 1994;125:903-8.

17) Kahler SG, Millington DS, Cederbaum SD, Vargas J, Bond LD, Maltby DA, et al. Parenteral nutrition in propionic and methylmalonic acidemia. J Pedeiatr 1989;115:235-41.

18) Lee EH, Ko JM, Kim JM, Yoo HW. Genotype and clinical features of Korean patients with methylmalonic aciduria and propionic aciduria. Korean J Pediatr 2008;51:964-70.

19) Jeon SH, Cheon HW, Yoo KH, Hong YS, Lee JW, Hahn SH. A case of methylmalonic academia. Neonatal Med 1998;5:61-6. 